\title{
CRITICAL READING: STUDENTS' PROBLEMS, STRATEGIES, AND REFLECTIONS
}

\author{
Galuh Nur Rohmah \\ UIN Maulana Malik Ibrahim \\ Malang \\ galuhnurrohmah@yahoo.com
}

\begin{abstract}
Critical reading has been considered as the highest level of reading behavior for English Department students. Students are expected to be able to critically read both nonfiction and fiction texts. This situation, for sure, has made EFL students face lot of problems. This study is intended to reveal students' problems, strategies, and reflections on critical reading. Revealing those three points becomes an academic effort to add knowledge about critical reading in the EFL reading comprehension course context. This study is approached through a descriptive qualitative research design which primarily focuses on students' written responses on open-ended questionnaire and interview. The EFL students who join in Reading Comprehension III were asked to give written responses based on statement starters. Then, by purposefully selecting students, they were interviewed to gain more information on their reflection. The findings reveal that students have both linguistic and non-linguistic problems in doing critical reading. The strategies they used cover both reading skill and non-reading skill strategies. The students reflect that reading III course has helped them to sharpen critical reading skill in terms of text analysis, summary writing, and questions development activities. It is suggested to engage students with more activities to evaluate and to develop questions. For further research, exploring effective strategies to read critically is highly recommended.
\end{abstract}

Keywords: Critical Reading. Students' Problems, Students' Strategies, Students' Reflections, EFL Reading Instruction

\section{INTRODUCTION}

Critical reading is valued as an essential part for students' reading proficiency. Lewis (1983) states that when it is taught, there will be citizens who are able to give judgments to what they read based on logical reasoning and facts, not subjective one. The importance of critical reading has inspired ELT researchers to intensively study it. Macknish (2011) conducted a small-scale action research for post-secondary ESL Chinese students in Singapore. The study reveals that the students engaged with critical reading discourse when they were facilitated with scaffolding and opportunities to practice. The importance of critical reading for academic success is also explored by Harris (2004) who uncovered the teacher's beliefs and knowledge about critical reading and academic writing. It is believed that being critical is supported by other great reading skills.

The way to teach students to be critical readers is, then, the major concern to EFL practitioners. When the text is discussed from various dimensions, to some extent, the teaching activity misses the point about how to provide questions or points of discussion leading to read critically. A study conducted by Haromi (2014) confirmed the idea about the role of teaching strategy for improving critical reading skill through an experimental study about the effect of teaching through appraisal on students' critical reading. The study reveals that the strategy gave a positive effect on the students' critical reading proficiency.

Questioning during teaching and learning process plays an important role to escalate students' critical reading. A case study about teachers' experiences in teaching reading to EFL Taiwanese students done by Ko (2013) reveals that critical questions and a critical dialogue with students facilitated to read out of the text on its literal level and made students aware of ideological issues raised in the text. The experiences, then, changed teachers practices toward more elevating pedagogy. The study also highlighted that giving a critical literacy approach to reading instruction was problematic due 
to some reasons such as a change in literacy practice, students' language learning beliefs, and teaching resources.

Focusing Reading Course in critical reading is in line with Harris (2004:3) who states that 'the ability to write a well-crafted, multiple-source research paper reveals the ability to read and think critically and write academically. These are necessary skills for high school and college success'. However, critical reading has been not the main concern in reading classroom. A study conducted by Bosley (2008) reveals that critical reading is not explicitly taught to college freshmen. The data from interview series with teachers and from documents become the evidence of the findings. There are two possible causes to the situation. As the research was done for freshmen, it might be not the time for teaching critical reading to them, or the reading classroom did not use the idea of reading to writing in the classroom. Reading or writing is part of a reader's or writer's process to gain very good literacy skills. Rosenblatt (1994) notes that goal setting (e.g. having a purpose for reading) was part of the transactional process of reading. She distinguished between efferent readings, during which readers take away information from a text, and aesthetic readings, during which readers' attentions are centered on what they are living through during their relationship with the text.

Akbari (2008) highlights the applications of critical pedagogy for L2 classrooms and provides hints as to how FL teaching can result in the improvement of the lives of those who are normally not considered in ELT discussions. In an attempt to detect the effect of raising students' critical reading ability through explicit teaching of some techniques of critical discourse analysis (CDA), Koupaee Dar, et al. (2010) conducted research on news articles reading which were selected from online editions. Students were asked to read critically which then there was any change in their attitudes towards or motivation to English critical reading comprehension. Overall, the study recorded a significantly positive effect of explicit teaching of CDA techniques on developing critical reading ability among EFL learners.

The complexities of critical reading inspire the researcher to have an exploration in the students' problems and strategies in critical reading, and their reflection. The study becomes one of key findings about the teaching of critical reading in the EFL context. The findings strengthen the importance of critical reading for students' academic success. This research is to answer questions on: 1.What problems do the students face in critical reading? 2. What strategies do the students employ in critical reading? and 3. How does Reading Course help the students improve critical reading skill? The findings are essential for having initial identification about critical reading. The study has practical contribution as well as pedagogical implication in English Language Teaching, particularly the teaching of reading.

\section{Literature Review}

A clear distinction has been made between critical and non-critical reading. Edge (2011) has stated that non-critical reading focuses on linear activities to have a textual recognition of a text. It aims to logically comprehend a text as a systematic structure consisting of information, ideas, and opinions of the author. Meanwhile critical reading is an analytic activity in which a reader intensively reads a text to identify text structures covering its information, values, assumptions, and language usage during the reading process. When reading critically, a reader involves total interpretation and evaluation on a text. Wang \& Gierl (2011, p. 169) also define that 'critical reading is the reading skills that involve a higher level of thinking in which the reader uses a questioning attitude, logical analysis, and inference to judge the worth of what is read'.

Critical reading can be recognized based on the following characteristics as stated by Huijie (2010) that 'examine' is as the key word. Once a reader critically reads a text, s/he starts with examining the evidence or arguments presented. Not only stop at that level, s/he also examines whether the evidence or arguments affect author's ideas, examines the strengths and weaknesses of the text, examines positive or negative interpretations of the author, and examines which author's point of view should be accepted or rejected. This characteristics have been mapped into three cognitive 'hierarchical stages' of the surface code (literal reading), the text base (basic inference by interconnecting the text)), and the situational model (making inferences through connecting the text and background knowledge) (Wang \& Gierl, 2011).

At a university level, students are expected to be able to develop and pose a higher level reading skill. Reading is an inseparable aspect in their study life. Before doing a presentation on a particular topic and writing an academic paper, students will do reading relevant texts to support their logical reasoning. Therefore, having a good critical reading skill should emphasize the reading class activity. However, based on an identification done by Wallace (2003, p. 4), students did not get sufficient exposure to experience critical reading. It was due to these following causes; limited time allocation, large classes, teachers' knowledge, and students' reading habit. More importantly, Wallace pointed that reading course was still emphasized on the surface structure of the text. A text is seen only from its semantic level. 


\section{METHOD}

\section{Research Design}

The research uses a descriptive qualitative method as it is to describe, explore, and find personal subjectivity which is socially constructed. The use of qualitative method helps to gain better and deeper understanding about the students' problems and strategies in critical reading. Reading III course is to facilitate students' critical reading skill as it is considered as the highest reading course allocated for the highest reading skill.

\section{Data Collection}

The data of the research are the students' responses to open-ended questionnaire on problems, strategies, and reflection on activities employed in the classroom. The participants are the fourth semester EFL students of Reading III. Those students are at the situation that requires them to read intensively on more advanced linguistic and literature courses.

\section{Data Analysis}

Firstly, data are mapped based on the three research questions. The students' reading problems are categorized into linguistic (vocabulary, sentence structure, content and organization, and topic and main idea) and non-linguistic problems (confusion and anxiety). The students' strategies are categorized into reading and non-reading strategies. The students' reflections are analyzed based on classroom activities they experienced. Interpretative devices such as interpretation and understanding on data are mostly done.

\section{FINDINGS}

\section{Findings}

$R Q$ 1: Students' problems

Problem 1: Language-related problems are related to the internal components of the text. Those are understanding unfamiliar vocabulary and phrases, limited vocabulary, unfamiliar idioms, compound words and phrasal verb, the whole meaning of every single words, guessing the meaning of the word without looking up in the dictionary, the high level of language in academic writing. Content-related problems belong to this area are difficult to understand the text and draw a conclusion completely, difficult to get all information from a whole text, get the main idea of the text, evaluate the arguments of the text, analyze the content, misinterpret the author's purpose, find the implicit meaning of the text, making relevant questions.

Problem 2: Non-linguistic problems. Problems belong to this category are less of concentration, having no interest in a specific topic, cannot find the appropriate answer for her own questions, giving the comment of the text, building the curiosity into the text, confuse about what have to do related critical reading, less of carefulness, less sensitive.

\section{Analysis}

Students still have very basic problems dealing with unfamiliar words. Students keep thinking that knowing and understanding every word help to gain the message. They did not realize that a text is constructed from a group of words representing author's idea, argument, and attitude. Identifying the main idea of the paragraph and finding the explicit purpose of the text were also problems faced. The explicit purpose is the stated information about what the text is about, what the author's intention is, and what for the text is written.

Students felt that they have poor concentration when reading. Concentration in reading is a basic requirement because all comprehension elements are from high quality of concentration. Having no interest in specific topic was the second non-linguistic problem. Some reading texts successfully raised the students' interests to read. Another problem resulted from lack of interest is that the students never feel curious to what they read. This is a crucial problem in critical reading. The last problem is the students are not sensitive to the text. Text sensitivity means the ability to see every single part of the text. They easily ignored the real main points but noticed less important details. The result of being insensitive is not feeling curious, lack of concentration, and confusion.

\section{$R Q$ 2: Students' strategies}

Strategy 1: Reading skill strategies

Skimming and scanning, asking questions, reviewing, using dictionary, re-reading the text, taking notes, highlighting, paraphrasing, analyzing text, summarizing, finding the key words, previewing, contextualizing, reflecting, evaluating, comparing related texts, concluding, identifying fact and opinion, finding thesis statements, interpreting text, using SQ3R strategies, drafting and mapping, understanding title, reading the introduction. 
Strategy 2: Non-reading strategies

Non-reading strategies are forcing to read, relaxing and enjoying, finding a quiet place, vocalization, reading with a pen in hand, sharing with friends, becoming part of writer's audience, openminded reader, reading from the interesting part, reading slowly, activating background knowledge.

Analysis

The very basic and useful strategies, scanning and skimming are two reading behaviors mostly applied. Active questioning is one of indicators to have a good reading process. Reviewing the text lets the students check some missing points. Dictionary use can be beneficial. Taking notes and highlighting are powerful strategies in reading since both only focus on the most important points. Making summary is also the best reading strategy for students. Drawing conclusion is also used by students. Drawing conclusion involved a strong ability to distinguish and evaluate facts and opinions.

Various strategies were applied to read critically. Raising intensity to read helped students to add vocabulary and to know sentence patterns, content and organization, and text types. Keeping relaxing and enjoying the reading activity are no more doubt to be one essential factor for improving reading skill. They had no pressure, stress, and burden to find any information they need. Interesting strategy is finding a quiet place to read. A quiet place made students not easily distracted by a crowd. One problem faced by students is lack of concentration. Vocalization is another strategy to comprehend. For some students, sharing with friends is beneficial. By sharing, other students also imitate other reading strategies to apply.

Becoming a part of writer's audience was an interesting strategy. The more involved to the text, the easier knowing the text. Another student said that reading interesting parts is a powerful strategy. In a text, there are various ways to present the idea. A writer uses quotations, figures, pictures or illustrations to attract the reader's attention. By connecting the background knowledge and the topic being discussed, at least, finding the topic of the text is easy. Keeping motivation to read is a good strategy because it is an asset to feel joyful, therefore, every single part of the text can be smoothly accessed by the student.

\section{RQ 3: Students' Reflection}

The course helped students to evaluate and understand the author's ideas, to be more sensitive and curious while reading a text, to analyze the text deeply and critically. Students wanted more practice through quizzes, helped to be more critical reader, helped to stimulate questions, and helped to be more open-minded.

\section{Analysis}

Reading course has made students more sensitive and curious toward the text. Curiosity is an important element in reading process because every single detail can be found when the students want to know more, more and more. The increase of curiosity is also caused by the different text types given to the students. Being exposed by different text types also makes the students have correct approach to read academic and non-academic texts critically. Assignments for text analysis and presentation help students to comprehend and share all details of the text. As an open-minded reader, having a balanced perspective on the text is important. Of course, the students cannot avoid judging views, but they remind themselves to be objective readers that a single text has strengths and weaknesses. They also reflect that the course needs to facilitate them to have more practices through quizzes.

\section{DISCUSSION}

Students' linguistic problems (vocabulary size and grammar) hinder their comprehension. Vocabulary mastery plays an important role in reading, as stated by Şen \& Kuleli (2015) that vocabulary size and vocabulary depth were significantly correlated to reading performance. However, vocabulary depth is not the only predictor to better reading performance. Nergis (2013) states that depth of vocabulary knowledge was not a strong predictor of academic reading comprehension. It was found that syntactic awareness was a significant predictor of academic reading comprehension. All the problems result in another problem, that is, anxiety. Being afraid of difficult words, complicated sentences structures, and unclear contents hesitated students to keep reading. Rajab, et al (2012) state that not many know that reading process is not just one person's understanding of each word and the surface structure of the reading text, but it also involves the comprehension process and the ability of the reader to actually interact with the reading text.

A lot of written information is available today, hence, students are required to access. Perry (2013) reminds that it is especially true for university students who, in the context of their studies, often need to search for and use information in English. Furthermore, the use and awareness of comprehension strategies is priority requirement. Lee (2012) shows that differences between male and 
female students on the types of reading strategies were significant. Male students were reported to have a greater strategy use than their female counterparts regarding memory, cognitive, and compensation strategies, while fewer males than females used strategies of meta-cognitive and socialaffective while reading. In addition, males were more worried about unknown words compared to their counterparts while reading.

Summarizing encourages students to figure out the details. Zafarani \& Kabgani (2014) examine the possible outcomes of the effectiveness summarization strategy on improving comprehension. Rereading and reviewing the text are helpful. Back and forth reading process is an absolute process as confirmed by Yeganeh (2013) that repeated reading (RR) can affect reading fluency and comprehension. Urlaub (2012) confirms that reading and discussing literary texts in a second language (L2) is a significant component of intermediate and advanced level of education. When the students enjoy reading, they can get any information they need. Also, there is a positive attitude towards reading. Walker (2015) states that students' positive reflection in reading is seen as the key way for university academic success. Good reading environment plays an important role to shape students' positive reflection. Morni \& Sahari (2014) explore the impact of living environment in fostering good reading habits. The more reading, the better and the leisure time is used to read. There is also a positive relationship between reading environment and average hours students spent on reading.

\section{CONCLUSIONS AND SUGGESTIONS}

The language-related problems in reading are caused by difficulties in vocabulary, syntactic structure, and the content of the text, while, non-linguistic problems deal with anxiety. The students use various comprehension strategies to cope with their reading problems. The strategies are categorized into reading skill and non-reading skill strategies. Students have some reflections to share. The reflections mostly described how reading course contributed to their reading development. The study brings pedagogical implications, especially, for the teaching of reading at higher level of education. The study also highlights that the course should teach students how to generate questions vis-à-vis texts to improve their ability to critically read literary texts in the second language. Studies about reading still provide some angles to explore, that is exploring on which effective comprehension strategy will be insightful to improve the teaching of reading. Studies on text types that help students to read critically is also another significant point to conduct.

\section{REFERENCES}

Akbari, R. (2008). Transforming lives: Introducing critical pedagogy into ELT classrooms. ELT Journal, 62: 276-283.

Bosley, L. (2008). I don't teach reading: Critical reading instruction in composition courses. Literacy research and instruction, 47: 285-308 DOI: 10.1080/19388070802332861

Haromi, F. A. (2014). Teaching through appraisal: Developing critical reading in Iranian EFL learners. Procedia. Social and Behavioral Sciences, 98: 127-136

Harris, C. D. (2004). An examination of teacher's beliefs about critical reading and academic writing. Unpublished Dissertation. San Diego State University and the University of San Diego

Huijie, L. (2010). Developing a hierarchical framework of critical reading proficiency. Chinese Journal of Applied Linguistics, 33: 40-54.

Ko, M-Y. (2013). A case study of an EFL teacher's critical literacy teaching in a reading class in Taiwan. Language Teaching Research, 17(1) 91-108, DOI: 10.1177/1362168812457537

Koupaee Dar, Z., Rahimi, A. \& Shams, M. R. (2010). Teaching reading with a critical attitude: Using critical discourse awareness to raise EFL university students' critical language awareness. International Journal of Criminology and Sociocultural Theory, 3: 457-476.

Lee, M. L. (2012). A Study of the selection of reading strategies among genders by EFL college students. Procedia - Social and Behavioral Sciences, 64: 310-319

Lewis, J. (1983). Influence of cognitive and ethical development on critical reading. Journal of College Reading and Learning, 16(1): 15-20. DOI: 10.1080/10790195.1983.10850208

Macknish, C. J. (2011). Understanding critical reading in an ESL class in Singapore. TESOL Journal, 2(4): 444-472

Morni, A \& Sahari, HS. (2013). The impact of living environment on reading attitudes Procedia - Social and Behavioral Sciences, 101(8), 415-425

Nergis, A. (2013). Exploring the factors that affect reading comprehension of EAP learners. Journal of English for Academic Purposes, 12: 1-9 
Galuh Nur Rohmah

Ölmez, F. (2015). An investigation into the relationship between L2 reading motivation and reading achievement. Social and Behavioral Sciences, 199: 597-609

Perry, D. (2013). Comprehension strategies while reading expository texts in Spanish (L1) and English (L2). Psicologia Educativa, 19: 75-81

Rajab, A et al. (2012). Reading anxiety among second language learners. Social and Behavioral Sciences, 66: 362-369

Rosenblatt, L.M. (1994). The reader, the text, the poem: The Transactional theory of the literary work. Illinois: SIU

Study guide student learning development. (2009). What is critical reading http://www2.le.ac.uk/

Şen, Y \& Kuleli, M. (2015). The effect of vocabulary size and vocabulary depth on reading in EFL context. Social and Behavioral Sciences, 199: 555-562

Urlaub, P. (2012). Reading strategies and literature instruction: Teaching learners to generate questions to foster literary reading in the second language. System, 40: 296-304

Wang, C \& Gierl, M.J. (2011). Using the attribute hierarchy method to make diagnostic inferences about examinees' cognitive skills in critical reading. Journal of Educational Measurement Summer, 48(2): 165-187

Walker, C. (2015). A study of self-concept in reading in a second or foreign language in an academic context. System, 49: 73-85

Yeganeh, M.T. (2013). Repeated reading effect on reading fluency and reading comprehension in monolingual and bilingual EFL Learners. Procedia - Social and Behavioral Sciences, 70: 17781786

Zafarani, P \& Kabgani, S. (2014). Summarization strategy training and reading comprehension of Iranian ESP learners. Procedia - Social and Behavioral Sciences, 98: 1959-1965

Wallace, C. (2003). Critical reading in language education. New York: Palgrave Macmillan 